\title{
The Potential of Prognostic Biomarkers of Uric Acid Levels in Coronary Heart Disease Among Aged Population: A Scoping Systematic Review of the Latest Cohort Evidence
}

\author{
Sidik Maulana $\mathbb{D}^{\prime}$, Aan Nuraeni ${ }^{2}$, Bambang Aditya Nugraha ${ }^{3}$ \\ 'Faculty of Nursing, Universitas Padjadjaran, Bandung, Indonesia; ${ }^{2}$ Department of Critical Care and Emergency Nursing, Faculty of Nursing, \\ Universitas Padjadjaran, Bandung, Indonesia; ${ }^{3}$ Department of Medical-Surgical Nursing, Faculty of Nursing, Universitas Padjadjaran, Bandung, Indonesia \\ Correspondence: Aan Nuraeni, Department of Critical Care and Emergency, Faculty of Nursing, Universitas Padjadjaran, Sumedang, Indonesia, \\ Tel + 62856242I7606, Fax +022-7795596, Email aan.nuraeni@unpad.ac.id
}

Background: This study sought to determine whether uric acid levels have a relationship with and can potentially be used as a prognosis for coronary heart disease (CHD) biomarkers using a scoping review.

Methods: This study was conducted following Arksey and O'Malley's scoping review framework. It was reported as obeying the Preferred Reporting Item for Systematic Review and Meta-analysis for Scoping Review (PRISMA-ScR). The subject was extensively searched for in PubMed, CINAHL, and ScienceDirect. The inclusion criteria in the study were that the sources were journal articles written in English and were available in full text. The age of the subject in the item is the elderly population to capture the relationship between uric acid levels and the prognosis of CHD. The publication time limit was 2010 to 2020 . The study was analyzed using thematic analysis.

Results: We identified 592 studies in our initial search, and 21 studies with a cohort design were included in this study's analysis. The majority of the evidence suggests an independent correlation with a poor prognosis of CHD in the elderly population. The prognosis of gout includes the prognosis of clinical outcome, severity, and mortality, all of which influence the prognosis value, which becomes a marker.

Conclusion: Uric acid levels have been identified as a potential biomarker for poor CHD prognosis. Nurses and other healthcare workers should learn how to control poor CHD prognosis.

Keywords: biomarker, coronary heart disease, prognosis, uric acid

\section{Introduction}

Uric acid's potential role is a two-edged sword; it is a determinant of the antioxidant system or a parameter of metabolic syndrome. ${ }^{1}$ Uric acid is a potent antioxidant in bodily fluids. On the one hand, it depletes approximately more than $70 \%$ of plasma's total antioxidant capacity, protecting against $\mathrm{CHD},{ }^{2-4}$ while, on the other, because it is one of the metabolic syndrome parameters, it positively correlates with $\mathrm{CHD} .{ }^{1}$

Recent pathophysiological studies have provided evidence that elevated uric acid levels (hyperuricemia) contribute to a poor coronary heart disease (CHD) prognosis. It is not clear how uric acid is correlated with CHD, but several studies suggest that elevated uric acid, also known as hyperuricemia, increases CHD risk by inducing endothelial dysfunction, oxidative stress, and interconnected inflammatory mechanisms. ${ }^{5,6}$ The clinical manifestations of CHD contribute to increased circulating uric acid levels in the arterial tissue, including coronary arteries. ${ }^{7}$ Impaired tissue reperfusion due to CHD activates circulating xanthine oxidase enzymes in the endothelium, leading to an increase in uric acid levels and, as a result, endothelial dysfunction. ${ }^{7}$ Thus, circulating uric acid as a result of reperfusion disorders has the potential to be a new biomarker in determining the prognosis of CHD. 
Several epidemiological studies have found a correlation between uric acid levels and coronary heart disease. ${ }^{8-10}$ These findings support the model's improvement in predicting CHD prognosis by taking uric acid levels into account. Recent meta-analysis studies on uric acid levels and CHD continue to provide a review of the relationship between uric acid levels and the risk of CHD morbidity and mortality. ${ }^{11-13}$ There are, however, no reviews that lead to the determination of clinical considerations related to uric acid as a biomarker to determine the prognosis of CHD, nor are there any that lead to the coverage of the elderly population. The study has a high priority in determining the considerations in establishing uric acid levels a biomarker of CHD prognosis, given the rising trend of the global elderly population. This study has implications for the nursing care process for the elderly with CHD by increasing uric acid levels, focusing on secondary prevention, and reducing the burden of patient care.

Furthermore, the condition of rising uric acid in the community affects a sizable number of people worldwide. ${ }^{14}$ The prevalence of gout increases with age, and the factor of decreased estrogen in the elderly affects the decrease in renal uric acid excretion and urate transporter 1 (URAT1); thus, serum uric acid levels rise. ${ }^{15}$ Furthermore, decreased kidney function due to degenerative processes raises serum uric acid levels, as a result of which the elderly with decreased metabolic function are more likely to increase uric acid.

Given the above conditions, this study update adds to the body of evidence regarding uric acid levels as a biomarker in predicting CHD prognosis in the elderly population. It is hoped that this review study can provide an evidence base for prognostication aids to help nurses and other health professionals offer effective secondary prevention in CHD patients. Therefore, the study aimed to summarize and explore the potential of the prognostic biomarker of the uric acid level in coronary heart disease among the elderly population. This review provides a theoretical basis for poor prognosis prevention.

\section{Methods}

\section{Study Design}

This study was conducted following Arksey and O'Malley's scoping review framework, ${ }^{16}$ which allows for the inclusion of extensive study designs to offer a full outline of the research topic. It was reported as obeying the Preferred Reporting Item for Systematic Review and Meta-analysis for Scoping Review (PRISMA-ScR). ${ }^{17}$ The scoping review methodology is suited for this subject because it allows for a thorough study of the relationship between CHD and poor prognostics among the elderly population. The review began with a broad research subject, restricted during the study process to allow a more thorough evaluation of the relationship between outcomes. ${ }^{18}$ The initial research question guided the initial search procedure and the study's primary outcome is to look into the relationship between uric acid levels and CHD prognosis, while the secondary outcome is to find the prognostic value that causes poor CHD prognosis. The objective of the present scoping review is to evaluate the latest cohort evidence on the potential of prognostic biomarkers of uric acid in CHD among the aged population. Therefore, the search was limited to the last ten years, 2010-2020.

\section{Search Strategy}

Three databases were used for the literature search: PubMed, CINAHL, and Science Direct. A literature search was conducted using keywords: coronary heart disease, uric acid, and prognosis.

\section{Eligibility Criteria}

The PICOS framework was used to determine the study strategy. Furthermore, full-text articles with a publication time limit of 2010 to 2020 had to be available in English.

P (Population): CHD patients

I (Interest): uric acid levels as a biomarker of CHD prognosis

C (Comparison): no comparison

$\mathrm{O}$ (Outcomes): the relationship or influence of interest on the prognosis of CHD

Study design: a cohort study 


\section{Data Collection and Analysis}

Three reviewers carried out the study selection process, and the included studies followed the PRISMA flow chart: (1) identifying duplicate articles; (2) screening of titles and abstracts; (3) checking full-text availability; and (4) screening full texts based on the study method and critical assessment criteria.

Data were manually extracted from the study results using Microsoft Excel (tabulation method). The included studies' quality was evaluated using the Joanna Briggs Institute (JBI) critical assessment. Three authors used the JBI critical assessment checklist for cohort studies to assess and report the risk of bias. Thematic descriptive analysis was used for each outcome analysis.

\section{Results}

\section{Description of Study Findings}

In the initial search results, 592 studies were found in the electronic databases. The authors screened 33 full-text articles and excluded ten studies with a cross-sectional design and two cohort studies that did not meet the critical appraisal cutoff. As a result, the authors included 21 cohort studies in this scoping review study. ${ }^{20-40}$ Figure 1 depicts the number of studies retrieved using the PRISMA flow chart diagram.

\section{Study Characteristics}

The authors identified a cohort study on the mean of the elderly population. They used a prospective and retrospective cohort design to examine the relationship between uric acid and CHD prognosis. Turkey $(\mathrm{n}=3)$, Singapore $(n=1)$, Israel $(n=1)$, Taiwan $(n=4)$, Germany $(n=2)$, Ukraine $(n=1)$, USA $(n=1)$, China $(n=1)$, Japan $(n=2)$, South Africa $(n=1)$, Denmark $(n=1)$, Spain $(n=1)$, France $(n=1)$, and Korea $(n=1)$ were the countries studied (See Table 1). The study included 82,727 CHD patients in various stages, including Acute Coronary Syndrome (ACS), stable angina, asymptomatic angina, ST-Elevation Myocardial Infarction (STEMI), and Acute Myocardial Infarction (AMI). They all underwent angiography and PCI procedures for both diagnosis and treatment due to stenosis and recurrent PCI due to restenosis. The study's follow-up period ranged between 1.2 and 8.1 years (see Table 2).

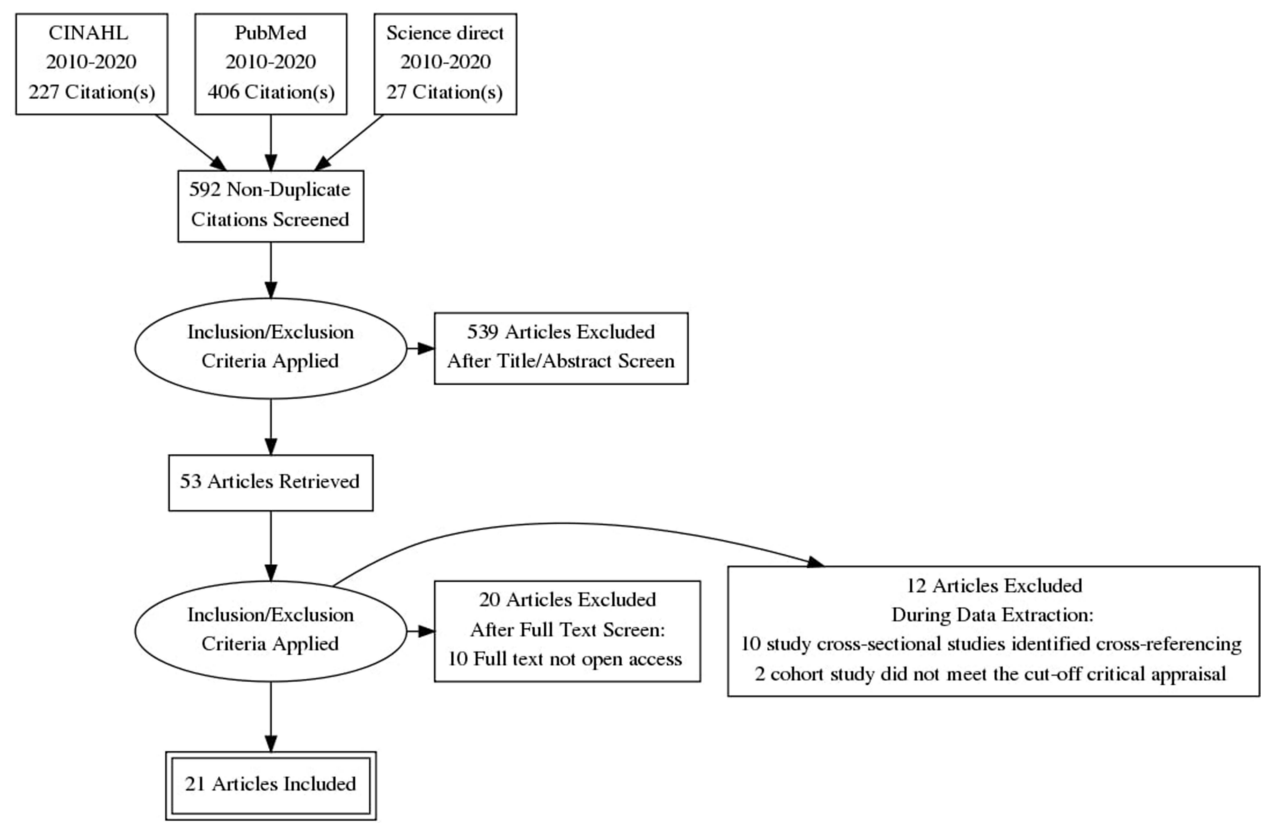

Figure I PRISMA flow diagram.

Note: Adapted from Liberati A, Altman D, Tetzlaff J, et al. The PRISMA statement for reporting systematic reviews and meta-analyses of studies that evaluate health care interventions: explanation and elaboration. Journal of Clinical Epidemiology. 2009;62(I0)e I-e34 ${ }^{19}$ 
Table I Characteristics of Study

\begin{tabular}{|c|c|c|c|c|c|}
\hline Study & Country & Age (Mean) & Participant & $\begin{array}{l}\text { Follow-Up } \\
\text { (Years) }\end{array}$ & $\begin{array}{l}\text { Critical } \\
\text { Appraisal }\end{array}$ \\
\hline $\begin{array}{l}\text { (Sinan Deveci et al., } \\
2010)^{40}\end{array}$ & Turkey & $59.4 \pm 10.24$ & 1012 patients with symptoms of CAD & $\mathrm{N} / \mathrm{I}$ & $7 / 11$ \\
\hline $\begin{array}{l}\text { (Duran et al., } \\
2012)^{30}\end{array}$ & Turkey & $59 \pm 12$ & 520 patients with ACS & $\mathrm{N} / \mathrm{I}$ & $6 / 11$ \\
\hline$(\text { Teng et al., } 2012)^{32}$ & Singapura & $45 \pm 74$ & 52.322 CHD patients & 8.1 & $10 / 11$ \\
\hline$(\text { Eisen et al., 2013) })^{34}$ & Israel & $45-74$ & 3122 stabile $C A D$ & 8 & $|I / I|$ \\
\hline$(\text { Lin et al., } 2013)^{26}$ & Taiwan & $\begin{array}{l}\text { Male }(M)=64.8 \\
\text { Female }(F)=66.9\end{array}$ & $\begin{array}{l}\text { I054 Angiographic confirmed CAD patients with } \\
>50 \% \text { stenosis }\end{array}$ & 3.1 & $11 / 11$ \\
\hline $\begin{array}{l}\text { (Ndrepepa et al., } \\
2013)^{22}\end{array}$ & Germany & $\begin{array}{l}M=\text { mean: } 65.6-67.1 \\
F=\text { mean: } 69.8-74.3\end{array}$ & I3.273 CAD patients & $\mathrm{N} / \mathrm{I}$ & $7 / 11$ \\
\hline$(\text { Li et al., } 2013)^{21}$ & Taiwan & $\begin{array}{l}\text { BMI> } 25 \text { group } \\
64.0 \pm 10.3(\mathrm{SUA}< \\
6.6) \\
64.5 \pm 10.9(\mathrm{SUA} \geq \\
6.6) \\
\mathrm{Ml} 25 \text { group } \\
66.5 \pm 10.5(\mathrm{SUA}< \\
6.6) \\
67.6 \pm 10.7(\mathrm{SUA} \geq \\
6.6)\end{array}$ & I,202 Angiography-confirmed CAD patients & 5.4 & $9 / 11$ \\
\hline $\begin{array}{l}(\text { Berezin \& Kremzer, } \\
2013)^{33}\end{array}$ & Ukraine & $58.34 \pm 9.60$ & 126 asymptomatic CAD patients & $\mathrm{N} / \mathrm{I}$ & $6 / 11$ \\
\hline $\begin{array}{l}\text { (Calvo et al., } \\
2014)^{38}\end{array}$ & USA & $\begin{array}{l}\text { White: } 64.6 \\
\text { Filipino: } 59.3\end{array}$ & $\begin{array}{l}202 \text { white women and I } 66 \text { postmenopausal } \\
\text { Filipino women }(N=368)\end{array}$ & 4.6 & $10 / 11$ \\
\hline$(\text { Yu et al., 2014) })^{31}$ & China & $\begin{array}{l}\text { Low: } 61.8 \pm 11.6 \\
\text { Moderate: } 64.6 \pm \\
10.2 \\
\text { High: } 64.6 \pm 10.2\end{array}$ & 347 patients & 1.10 & $9 / 11$ \\
\hline$(\text { Liu et al., 2014) })^{25}$ & Taiwan & $\begin{array}{l}\text { Gout group: } 61.08 \pm \\
13.69 \\
\text { Control group: } \\
60.72 \pm 12.90\end{array}$ & 444 patients with STEMI & $\begin{array}{l}49 \pm 28 \\
\text { month }\end{array}$ & $8 / 11$ \\
\hline $\begin{array}{l}\text { (Baumann et al., } \\
2016)^{20}\end{array}$ & Germany & $62.5 \pm 13.4$ & 803 STEMI patients undergoing primary $\mathrm{PCl}$ & $\mathrm{N} / \mathrm{I}$ & $8 / 11$ \\
\hline $\begin{array}{l}\text { (Ando et al., } \\
2016)^{23}\end{array}$ & Japan & $69.1 \pm 10.9$ & 385 patients undergoing $\mathrm{PCl}$ & $\mathrm{N} / \mathrm{I}$ & $8 / 11$ \\
\hline $\begin{array}{l}\text { (Kawabe et al., } \\
2016)^{36}\end{array}$ & Japan & $\begin{array}{l}M=64.5 \pm 11.7 \\
F=72.1 \pm 10.6\end{array}$ & I 380 patients with ACS & I.2 (437 days) & $8 / 11$ \\
\hline $\begin{array}{l}\text { (Ranjith et al., } \\
2017)^{35}\end{array}$ & $\begin{array}{l}\text { South } \\
\text { Africa }\end{array}$ & $51.7 \pm 11.5$ & 2683 patients with AMI & $\mathrm{N} / \mathrm{I}$ & $7 / 11$ \\
\hline
\end{tabular}

(Continued) 
Table I (Continued).

\begin{tabular}{|c|c|c|c|c|c|}
\hline Study & Country & Age (Mean) & Participant & $\begin{array}{l}\text { Follow-Up } \\
\text { (Years) }\end{array}$ & $\begin{array}{l}\text { Critical } \\
\text { Appraisal }\end{array}$ \\
\hline $\begin{array}{l}\text { (Larsen et al., } \\
2018)^{29}\end{array}$ & Denmark & 59.4 & 1039 patients with suspected or definite AMI & & $9 / 11$ \\
\hline$(\text { Liu et al., 2017) })^{24}$ & Taiwan & 57 & 95I STEMI patients undergoing $\mathrm{PCl}$ & $\mathrm{N} / \mathrm{I}$ & $6 / 11$ \\
\hline $\begin{array}{l}\text { (Lopez-Pineda et al., } \\
2018)^{28}\end{array}$ & Spain & $68 \pm 13$ & III9 patients with ACS & 3 & $10 / 11$ \\
\hline $\begin{array}{l}\text { (Gaubert et al., } \\
2018)^{37}\end{array}$ & France & $67.8 \pm 9.4$ & $\begin{array}{l}80 \text { patients with first episode of non-ST segment } \\
\text { ACS }\end{array}$ & $N / I$ & $7 / 11$ \\
\hline$\left(\right.$ Joo et al., 2018) ${ }^{27}$ & Korea & $\begin{array}{l}\text { Normal uric acid }= \\
64.6 \pm 9.9 \\
\text { High uric acid }=65.3 \\
\pm 10.3\end{array}$ & 317 restenotice patients undergoing repeated $\mathrm{PCl}$ & 1088 days $(3)$ & $10 / 11$ \\
\hline $\begin{array}{l}\text { (Karabağ et al., } \\
2019)^{39}\end{array}$ & Turkey & $62.2 \pm 10.96$ & 331 patients with stable angina pectoris & $505 \pm 13$ days & $10 / 11$ \\
\hline
\end{tabular}

\section{Risk of Bias}

According to the risk of bias assessment, the overall quality of the 23 cohort studies had low risk of bias. Figure 2 shows that several studies had a high risk of bias reporting follow-up studies (11 studies/47.8\%).

\section{The Correlation Between Uric Acid Levels and CHD Prognosis}

This study found various evidence of the causality of uric acid and CHD prognosis, with the identified prognostic components including clinical outcome, severity, and mortality. A clinical outcome refers to the incidence (first or new diagnosis), prevalence, and recurrence. ${ }^{41}$ Severity is defined as an outcome that refers to the degree of obstruction as measured by various clinical vessel score indice, while mortality is defined as the number of deaths recorded in the death record or during the study's follow-up period. The findings yielded a three-component thematic model explaining the role of uric acid levels in a poor prognosis: clinical outcome, severity, and mortality. The review found that each component of the thematic model of uric acid levels as a prognostic biomarker of CHD was interrelated in the poor prognosis of coronary heart patients. The review's findings show that clinical outcomes and severity impact each other, and both have an impact on the risk of CHD death (see Table 1).

\section{Theme I: Clinical Outcome Prognosis}

The primary studies have found a correlation between uric acid levels and clinical outcome prognosis. Measurement of $\mathrm{CCV}$, calcification; plaque components, endothelial dysfunction with Reactive Hyperemia (RH), the severity of atherosclerosis, MAE (non-fatal myocardial infarction and revascularization), and MACE were identified as studies that provided evidence of a significant clinical outcome relationship (heart failure, AF, complete heart block, cardiogenic shock, ventricular arrhythmias, infarction recurrence and angina, and cerebrovascular events). ${ }^{33}$ Meanwhile, two studies concluded that they had a significant effect on the prognosis of CHD clinical outcomes. MACE and CAC severity were identified as clinical outcomes with no significant relationship. ${ }^{19}$

There are several modalities for determining the clinical outcome prognosis of CHD, including angiography, CT, echocardiogram, ECG, cardiac enzyme biochemistry, non-invasive peripheral arterial tonometry (PAT), endo PAT, and Integrated Backscatter Intravascular Ultrasound (IB-IVUS). Each modality was only used to assess a subset of clinical outcomes (see Table 2). 
Table 2 Summary of Finding

\begin{tabular}{|c|c|c|c|}
\hline Study & Measurement & Measurement Methods & Findings \\
\hline $\begin{array}{l}(\text { Sinan } \\
\text { Deveci et } \\
\text { al., } 2010)^{40}\end{array}$ & The severity with clinical vessel score indicator & Angiography & $\begin{array}{l}\text { Uric acid has a significant relationship with } \\
\text { severity prognosis }(p<0.00 \mathrm{I}) \text {. } \\
\text { Improved severity prognosis associated with } \\
\text { increased uric acid based on quartile increase in } \\
\text { uric acid, } p=0.015\end{array}$ \\
\hline $\begin{array}{l}\text { (Duran et } \\
\text { al., 20I2) }\end{array}$ & $\begin{array}{l}\text { Coronary Collateral Vessel }(\mathrm{CCV}) \text { with } \\
\text { Rentrop classification }\end{array}$ & Angiography & $\begin{array}{l}\text { The presence of } C C V \text { was associated with } \\
\text { lower serum uric acid levels }(p<0.00 I) \\
C C V \text { development was associated with lower } \\
\text { uric acid levels ( } p=0.003)\end{array}$ \\
\hline $\begin{array}{l}\text { (Teng et al., } \\
2012)^{32}\end{array}$ & Mortality & $\begin{array}{l}\text { International Classification of } \\
\text { Diseases (ICD)-10 }\end{array}$ & $\begin{array}{l}\text { Patients with gout have a higher risk of } \\
\text { mortality from CHD than non-gout (HR I.38, } \\
95 \mathrm{Cl} \text { I.10-I.73) }\end{array}$ \\
\hline $\begin{array}{l}(\text { Eisen et } \\
\text { al., 2013) }\end{array}$ & Heart failure & $\begin{array}{l}\text { New York Heart Association } \\
\text { (NYHA) Classification }\end{array}$ & $\begin{array}{l}\text { Uric acid levels are associated with heart failure } \\
\text { with } \mathrm{HR} \text { adjusted for age (HR I.I6; } 95 \% \mathrm{Cl} \\
0.94-\mathrm{I} .45) \text { and (HR I,28; } 95 \% \mathrm{Cl} \text { I.04-I.59) in } \\
\text { tertiles } 2 \text { and } 3 . \text { Meanwhile, HR adjusted for } \\
\text { several confounders (HR I.I8; } 95 \% \mathrm{Cl} 0.95 \text { - } \\
\text { I.47) dan (HR I.25 } 95 \% \mathrm{Cl} \text { I.00-I.56) in tertile } \\
2 \text { and } 3 \text {. }\end{array}$ \\
\hline $\begin{array}{l}\text { (Lin et al., } \\
2013)^{26}\end{array}$ & Mortality & Death certificate & $\begin{array}{l}\text { Elevated uric acid causes a } 2.08 \text {-fold } \\
\text { independent mortality risk mortality (HR 2.08; } \\
95 \% \mathrm{Cl} \text { I.19-3.65; } \mathrm{p}=0.0 \mathrm{I} \text { ) viewed from the } \\
\text { highest quartile. }\end{array}$ \\
\hline $\begin{array}{l}\text { (Ndrepepa } \\
\text { et al., } \\
2013)^{22}\end{array}$ & I-year mortality & $\begin{array}{l}\text { Hospital records and death } \\
\text { certificates }\end{array}$ & $\begin{array}{l}\text { Uric acid is an independent predictor of I-year } \\
\text { mortality (HR I. I7; } 95 \% \text { Cl I.03-I.3I; } p=0.0 \text { I } ; \\
\text { male) dan (HR I.25; } 95 \% \text { Cl I.06-I.48; } p=0.007 \text {; } \\
\text { Female) }\end{array}$ \\
\hline $\begin{array}{l}(\text { Li et al., } \\
20 \mid 3)^{21}\end{array}$ & Mortality & $\begin{array}{l}\text { The death certificate and } \\
\text { database }\end{array}$ & $\begin{array}{l}\text { Independently, higher uric acid levels cause } \\
\text { higher mortality in obese } \mathrm{CHD} \text { patients (HR } \\
\text { I.79; } 95 \% \mathrm{Cl} \text { I.I4-2.82; } \mathrm{P}=0.023 \text { ), but obesity is } \\
\text { not a predictor (HR } 0.91 ; 95 \% \mathrm{Cl} 0.62-1.32 \text { ) }\end{array}$ \\
\hline $\begin{array}{l}(\text { Berezin \& } \\
\text { Kremzer, } \\
2013)^{33}\end{array}$ & Calcification with Agatston score index & $\begin{array}{l}\text { Contrast-enhanced spiral } \\
\text { Computed Tomography (CT) } \\
\text { angiography }\end{array}$ & $\begin{array}{l}\text { The uric acid level is an independent predictor } \\
\text { of } \mathrm{CHD} \text { (HR I.I2; } 95 \% \mathrm{Cl} \text { I.0I-I.52; } \mathrm{p}<0.00 \mathrm{I})\end{array}$ \\
\hline $\begin{array}{l}\text { (Calvo et } \\
\text { al., } 2014)^{38}\end{array}$ & $\begin{array}{l}\text { Severity and progression } \\
\text { Coronary Artery Calcium (CAC) with } \\
\text { Agatston index score }\end{array}$ & $\begin{array}{l}\text { Electron Beam Computed } \\
\text { Tomography (EBCT) }\end{array}$ & $\begin{array}{l}\text { Uric acid levels independently caused CAC } \\
\text { severity in the Filipino group (OR I.34; } 95 \% \mathrm{Cl} \\
\text { I.05-I.7I) and not for the white group (OR } \\
0.94 ; 95 \% \mathrm{Cl} 0.7 \mathrm{I}-\mathrm{I} .25 \text { ) } \\
\text { Uric acid levels independently led to CAC } \\
\text { development in both groups (OR I.26; } 95 \% \mathrm{Cl} \\
\mathrm{I} .02-\mathrm{I} .56 \text { ). }\end{array}$ \\
\hline
\end{tabular}

(Continued) 
Table 2 (Continued).

\begin{tabular}{|c|c|c|c|}
\hline Study & Measurement & Measurement Methods & Findings \\
\hline $\begin{array}{l}\text { (Yu et al., } \\
2014)^{31}\end{array}$ & $\begin{array}{l}\text { Severity, Major Advance Cardiac Events } \\
\text { (MACE), Mortality }\end{array}$ & $\begin{array}{l}\text { Angiography and SYNergy } \\
\text { between PCI with TAXUSTM } \\
\text { and Cardiac Surgery } \\
\text { (SYNTAX) score }\end{array}$ & $\begin{array}{l}\text { Uric acid levels were independently correlated } \\
\text { with high SYNTAX scores }(B=0.33,95 \% \mathrm{Cl} \\
0.023-0.042, p<0.00 \mathrm{I}) \text {. } \\
\text { Comparison with normal uric acid levels, high } \\
\text { uric acid levels tend to increase SYNTAX } \\
\text { scores ( } p<0.000 \mathrm{I}) \\
\text { Uric acid levels are positively correlated with } \\
\text { MACE ( }<<0.00 \mathrm{I}) \\
\text { Kaplan-Meier analysis showed that event-free } \\
\text { survival was higher in the high uric acid group } \\
(p<0.00 \mathrm{I})\end{array}$ \\
\hline $\begin{array}{l}\text { (Liu et al., } \\
2014)^{25}\end{array}$ & $\begin{array}{l}\text { Adverse non-fatal cardiac event (Unstable } \\
\text { angina, symptomatic arrhythmias, repeated } \\
\text { revascularization, recurrent infarction, } \\
\text { rehospitalization due to heart failure) }\end{array}$ & $\begin{array}{l}\text { Electrocardiography (ECG), } \\
\text { cardiac enzyme checks, } \\
\text { hospital documentation }\end{array}$ & $\begin{array}{l}\text { Gout is independently associated with short } \\
\text { and long term adverse non-fatal cardiac events } \\
(\mathrm{HR} \mathrm{I}, 88,95 \% \mathrm{Cl} \text { I.09-3.24, } \mathrm{p}=0.024 \text {; HR } 1.82 \text {. } \\
95 \% \mathrm{Cl})\end{array}$ \\
\hline $\begin{array}{l}\text { (Baumann } \\
\text { et al., } \\
2016)^{20}\end{array}$ & Major Adverse Cardiac Events (MACE) & $\begin{array}{l}\text { Coronary angiography, } \\
\text { echocardiography }\end{array}$ & $\begin{array}{l}\text { Uric acid was not a significant predictor of } \\
\text { MACE (AUC: } 0.59 ; 95 \% \mathrm{Cl} 0.5 \mathrm{I}-0.65 ; \mathrm{p}=0.83 \text { ) }\end{array}$ \\
\hline $\begin{array}{l}\text { (Ando et } \\
\text { al., 2016) }\end{array}$ & Coronary plaque components & $\begin{array}{l}\text { Integrated Backscatter } \\
\text { Intravascular Ultrasound (IB- } \\
\text { IVUS) }\end{array}$ & $\begin{array}{l}\text { Uric acid levels were correlated with the } \\
\text { percentage of lipid volume }(r=0.37 \mathrm{I}, \mathrm{p}<0.00 \mathrm{I}) \\
\text { and inversely with fiber volume }(r=-0.347, \mathrm{p}< \\
0.00 \mathrm{I}) \text {. } \\
\text { Uric acid levels were independently correlated } \\
\text { with lipid-rich plaque (OR } 2.43 ; 95 \% \mathrm{CI} \text { I.75- } \\
3.47) \text {. }\end{array}$ \\
\hline $\begin{array}{l}\text { (Kawabe et } \\
\text { al., 2016) }\end{array}$ & $\begin{array}{l}\text { Major Adverse Cardiac Events (MACE): } \\
\text { mortality, heart failure, infarction, and stroke }\end{array}$ & $\begin{array}{l}\text { Computed Tomography (CT)/ } \\
\text { Magnetic Resinance Imaging } \\
\text { (MRI) }\end{array}$ & $\begin{array}{l}\text { Uric acid level was an independent predictor of } \\
\text { MACE in women (HR 2.84; } 95 \% \mathrm{Cl} \text { I. } 19-6.77 \text {; } \\
\mathrm{P}=0.018 \text { ), but not significant in men (HR I.32; } \\
95 \% \mathrm{Cl} 0.66-2.64 ; \mathrm{p}=0.422)\end{array}$ \\
\hline $\begin{array}{l}\text { (Ranjith et } \\
\text { al., 2017) }\end{array}$ & $\begin{array}{l}\text { Major Adverse Cardiac Events (MACE): heart } \\
\text { failure, mortality, AF, complete heart block, } \\
\text { cardiogenic shock, ventricular arrhythmias, } \\
\text { recurrence of infarction and angina, and } \\
\text { cerebrovascular events }\end{array}$ & $\mathrm{N} / \mathrm{l}$ & $\begin{array}{l}\text { Hyperuricemia significantly and independently } \\
\text { caused mortality risk (OR I.7; } 95 \% \mathrm{CI} I .0-2.8 \text {; } \\
P=0.042) \\
\text { High above-normal uric acid levels in tertiles } \\
\text { correlated with a significant increase in MACE } \\
(p<0.00 \mathrm{I}) \text {, especially for heart failure }(p<0.00 \mathrm{I}) \\
\text { and mortality }(p=0.006) \text {. }\end{array}$ \\
\hline $\begin{array}{l}\text { Larsen et } \\
\text { al., } 2018)^{29}\end{array}$ & Severity of CAC & Non-contrast CT Scan & $\begin{array}{l}\text { There is no relationship between uric acid and } \\
\text { CAC severity. }\end{array}$ \\
\hline $\begin{array}{l}\text { (Liu et al., } \\
2017)^{24}\end{array}$ & Death on Killip class & $\begin{array}{l}\text { Records of patients who come } \\
\text { to the ED }\end{array}$ & $\begin{array}{l}\text { In Killip class I, hyperuricemia was associated } \\
\text { with mortality at one year (HR } 5.176 ; 95 \% \mathrm{Cl} \\
\text { I.488-I8007; } \mathrm{p}=0.0 \mathrm{I}) \text { and for } 30 \text { days (HR } \\
\text { II.204; } 95 \% \mathrm{CI} \text { I.I23-I II.8; } \mathrm{p}=0.047) \text {, but had } \\
\text { no association. on Killip class II-IV }\end{array}$ \\
\hline
\end{tabular}

(Continued) 
Table 2 (Continued).

\begin{tabular}{|c|c|c|c|}
\hline Study & Measurement & Measurement Methods & Findings \\
\hline $\begin{array}{l}\text { (Lopez- } \\
\text { Pineda et } \\
\text { al., 2018) }\end{array}$ & $\begin{array}{l}\text { Mid-term and long-term clinical outcomes and } \\
\text { results after addition to the GRACE score }\end{array}$ & $\begin{array}{l}\text { Cardiology notes, } \\
\text { echocardiography }\end{array}$ & $\begin{array}{l}\text { Independently, hyperuricemia was associated } \\
\text { with cardiovascular death (HR I.9I; } 95 \% \mathrm{Cl} \\
\text { I.32-2.28; } \mathrm{p}<0.0 \mathrm{I} \text { ), all disease mortality (HR } \\
\text { I.59; } 95 \% \mathrm{Cl} \text { I.I8-2.I5; } \mathrm{p}<0.0 \mathrm{I}) \text {, major } \\
\text { cardiovascular events (HR I.36; } 95 \% \mathrm{Cl} \text { I.II- } \\
\text { I.67; } \mathrm{p}<0.0 \mathrm{I} \text { ). Addition of hyperuricemia to } \\
\text { GRACE increased the risk of } 38 \% \text { of the total } \\
\text { participants. }\end{array}$ \\
\hline $\begin{array}{l}\text { (Gaubert } \\
\text { et al., } \\
2018)^{37}\end{array}$ & $\begin{array}{l}\text { Endothelial dysfunction with reactive hyperemia } \\
(\mathrm{RH}) \text { and severity of atherosclerosis }\end{array}$ & $\begin{array}{l}\text { Non-invasive peripheral } \\
\text { arterial tonometry (PAT) and } \\
\text { angiography }\end{array}$ & $\begin{array}{l}\text { The uric acid level had a significant relationship } \\
\text { with Reactive Hyperemia Index/RHI }(\beta=-0.17 \text {, } \\
p<0.00 \text { I), and the uric acid level was associated } \\
\text { with the Gensini score and SYNTAX score } \\
(p<0.00 I)\end{array}$ \\
\hline $\begin{array}{l}(J 00 \text { et al., } \\
2018)^{27}\end{array}$ & $\begin{array}{l}\text { Major adverse event (MAE): the cause of all } \\
\text { mortality, non-fatal myocardial infarction, and } \\
\text { revascularization. }\end{array}$ & Angiography & $\begin{array}{l}\text { Uric acid was not an independent predictor of } \\
\text { MAE (HR I.I I0; } 95 \% \mathrm{Cl} 0.980-1.257 ; p=0.100)\end{array}$ \\
\hline $\begin{array}{l}\text { (Karabağ } \\
\text { et al., } \\
2019)^{39}\end{array}$ & SYNTAX score II (SII) and long-term mortality & Angiography & $\begin{array}{l}\text { Uric acid and SYNTAX independent predictors } \\
\text { of long-term mortality (HR I.24, } 95 \% \mathrm{Cl} \text { I.046- } \\
\text { I.482, } \mathrm{p}=0.014 \text {; HR I.042, } 95 \% \mathrm{Cl} \text { I.007- } 1.079 \text {, } \\
p=0.018)\end{array}$ \\
\hline
\end{tabular}

\section{Theme 2: Severity Prognosis}

According to the study findings, there was a significant relationship between uric acid levels and prognosis severity. ${ }^{31,40}$ There were differences found in the indicators and modalities used to assess prognosis when using the clinical vessel score indicator, measured with angiography, and angiography with the SYNTAX score index. ${ }^{31,40}$

\section{Theme 3: Mortality Prognosis}

This study found evidence that uric acid levels were independently associated with the prognosis of CHD mortality. The hazard ratio of uric acid causing death is between 1.110 and 5.176 times. ${ }^{21,22,24,26,28,31,32,35,36,39}$ Several studies, however, call the evidence for a correlation into question, claiming that there is no significant relationship between uric acid levels

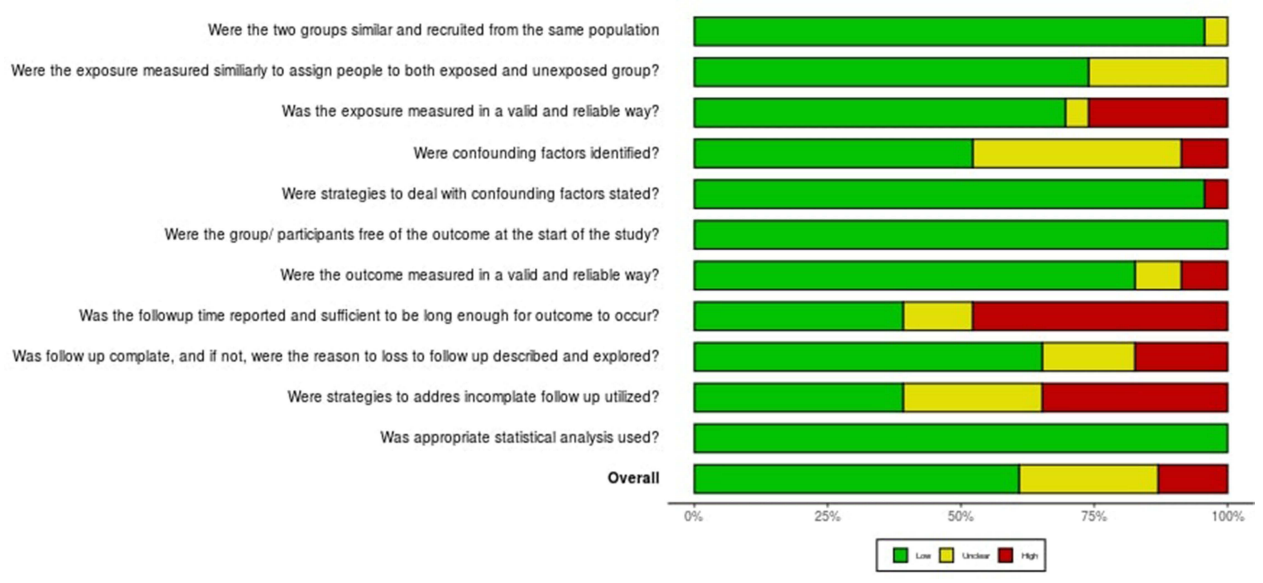

Figure 2 Risk of bias. 
Table 3 Cut off Uric Acid as a Predictor of Poor Prognosis

\begin{tabular}{|l|l|l|l|l|}
\hline Study & Type of Prognosis & Value & Sensitivity & specificity \\
\hline $\begin{array}{l}\text { (Sinan Deveci et al., 20I0) } \\
(\text { Duran et al., 20I2) }\end{array}$ & $\begin{array}{l}\text { Clinical vessel score } \\
\text { CCV }\end{array}$ & $\begin{array}{l}6.86 \mathrm{mg} / \mathrm{dl} \\
5.8 \mathrm{mg} / \mathrm{dl}\end{array}$ & - & - \\
\hline (Ndrepepa et al., 20I3) $^{22}$ & Mortality & $\begin{array}{l}\text { Male= } 6.8 \mathrm{mg} / \mathrm{dl} \\
\text { female= } 6.2 \mathrm{mg} / \mathrm{dl}\end{array}$ & $\begin{array}{l}\text { Male= } 59 \% \\
\text { Female= } 61 \%\end{array}$ & $\begin{array}{l}\text { Male= } 59 \% \\
\mathrm{female}=62 \%\end{array}$ \\
\hline (Berezin \& Kremzer, 2013) $^{33}$ & Arterial calcification & $35.9 \mathrm{mmol} / \mathrm{dl}$ & $80.0 \%$ & $59.2 \%$ \\
\hline (Karabağ et al., 2019) $^{39}$ & SYNTAX score II (SSII) & $>4.45$ & $82 \%$ & $35 \%$ \\
\hline
\end{tabular}

and CHD mortality prognosis. ${ }^{19,27}$ Hospital records or death certificates are used to determine a person's mortality prognosis.

\section{Value of Prognosis}

The secondary aim of this scoping review is to identify the prognostic value that causes poor CHD prognosis. In each study, the prognostic value ranged from 4.45 to $6.86 \mathrm{mg} / \mathrm{dL}$ (see Table 3). According to the area under the ROC curve taken from the study by Ndrepepa et al (2013), the predictive accuracy of uric acid in causing death for one year was 0.625 ; $95 \%$ CI $0.594-0.656, \mathrm{p}<0.001 .{ }^{22}$ The uric acid levels that predicted mortality were $6.2 \mathrm{mg} / \mathrm{dl}$ ( $61 \%$ sensitivity; $62 \%$ specificity) in women and $6.8 \mathrm{mg} / \mathrm{dl}$ in men (sensitivity $59 \%$; specificity $59 \%$ ).

According to Berezin and Kremzer (2013), the accuracy of uric acid leading to the clinical prognosis of calcifications was $35.9 \mathrm{mmol} / \mathrm{L}$ with a sensitivity of $80.0 \%$ and a specificity of $59.2 \%$ based on ROC analysis. ${ }^{33}$ The uric acid value associated with an increase in the SYNTAX score, according to Karabağ et al (2019), was $>4.45$ with an $82 \%$ sensitivity and a $35 \%$ specificity (ROC $0.604 ; 95 \%$ CI $0.538-0.670 ; \mathrm{p}=0.001) .{ }^{39}$

\section{Discussion}

This study is the first scoping review related to identifying the correlation between uric acid levels and the prognosis of CHD. The review of several cohort studies show that (1) uric acid levels are associated with CHD prognosis in the elderly population, (2) CHD prognosis related to uric acid levels includes clinical outcome, severity, and mortality prognosis, and (3) distinct prognostic values are for clinical outcome prognosis, severity, and mortality.

Previous meta-analyses have identified a correlation between uric acid levels and a variety of CHD outcomes. Previous research by ${ }^{5}$ revealed a correlation between uric acid levels and the risk of poor clinical outcomes in the form of coronary artery calcification in the CHD patient population; with every $1 \mathrm{mg} / \mathrm{dl}$ uric acid increase, the risk of CAC increased by $31 \%$. Furthermore, the study by ${ }^{12}$ found a correlation between uric acid levels and the prognosis of CHD mortality; with every $1 \mathrm{mg} / \mathrm{dl}$ uric acid increase, mortality increased by $9 \%$, but the missing adjustment needed for diuretic use and renal functioning was identified as a shortcoming in their meta-analysis. The elderly are more likely to suffer renal function disorders, diabetes, and hypertension than the younger population.

According to Zuo et al's (2016) study subgroup analysis, uric acid increased CHD mortality in women (RR 1.47; 95\% CI 1.21-1.73) more than in men (RR 1.47; 95\% CI 1.00-1.19). Based on the following two meta-analyses, there is no available synthesis of whether uric acid is associated with prognosis. Although neither meta-analysis explicitly stated the correlation with prognosis, the study shares some similarities with the previous meta-analysis, which looked at the correlation of uric acid levels with one component of poor CHD prognosis from cohort studies. This scoping review provides more comprehensive evidence to reach a descriptive conclusion and includes the relationship between uric acid levels and the prognosis of CHD, including clinical outcome prognosis, severity, and mortality among the elderly population recruited from various studies. The elderly are prone to reduced metabolism, one of which is uric acid metabolism. Thus, according to the final CHD prognosis prediction model, age is a predictor of poor CHD prognosis. ${ }^{42}$ 
Although the role of uric acid levels in the prognosis of CHD is unclear, several studies have described its mechanism, which may be used as a reference. Firstly, uric acid causes calcification, slowing coronary blood flow. ${ }^{43,44}$ Furthermore, increased uric acid causes oxidative stress and LDL cholesterol oxidation, resulting in decreased coronary blood flow. ${ }^{44}$ As a result, this mechanism supports the correlation between uric acid levels and clinical prognosis in calcification and CCV. Secondly, uric acid causes endothelial dysfunction, which is a precursor to the development of atherosclerosis. ${ }^{45}$ The hardening of urate crystals in the walls of coronary blood vessels can cause an inflammatory response, which directly causes injury to the intima of the coronary vessels and, ultimately, activates platelets and the coagulation system. ${ }^{12}$ These mechanisms contradict the notion that uric acid is associated with the clinical prognosis of endothelial dysfunction and atherosclerosis. Finally, increased uric acid levels cause thrombotic activity and the activation of chemotaxis proteins, resulting in a severe prognosis with clinical prognoses such as stroke, heart failure, ventricular fibrillation, and death. ${ }^{46}$

Experimental and other studies indicate that uric acid worsens CHD prognosis via oxidative stress, endothelial dysfunction, and inflammation pathways. With a high enough affinity to interfere with nitric oxide, uric acid can activate xanthine oxidase, causing uric acid synthesis, which, in turn, produces oxygen-free radicals. ${ }^{7}$ Uric acid also inhibits endothelial proliferation, interfering with nitric oxide production, which aids in coronary vasodilation. Nitric oxide reduction caused by uric acid results in oxidative stress, which causes endothelial dysfunction and a pathological role in CHD. ${ }^{47}$ Furthermore, uric acid deposited in plaque stimulates smooth muscle cell proliferation by producing proinflammatory, pro-oxidative, and vasoconstrictive substances that cause endothelial dysfunction and the development of $\mathrm{CHD}^{46}$

Urate-lowering therapy research has become a significant focus in improving cardiovascular treatment outcomes. The use of allopurinol, a xanthine inhibitor, can help to lower uric acid levels. A cohort study $(\mathrm{n}=65,971)$ found that allopurinol was associated with a reduction in MACE, defined as a combination of infarction, stroke, and cardiovascular death. ${ }^{48}$ Urate-lowering therapy research has become a major focus in improving cardiovascular treatment outcomes. ${ }^{49}$ Although recent studies mentioned that some clinical benefits of urate-lowering medication had been demonstrated in small studies, the efficacy of urate-lowering therapy in large-scale trials has yet to be established. ${ }^{50}$ Based on the findings of both studies, it is possible to conclude that pharmacology-based therapy has evolved into a modality that can be used to prevent poor CHD prognosis. At the same time, it remains unknown as to whether uric acid is a risk factor for cardiovascular disease. Furthermore, non-pharmacological efforts can be used as a supplement to improve the prevention of poor CHD prognosis associated with increased uric acid.

Several studies have shown that non-pharmacological therapy can be used to reduce uric acid levels. Nonpharmacological interventions to prevent elevated uric acid levels include a low-purine diet, Mediterranean, and vitamin. ${ }^{51,52}$ Furthermore, physical activity is associated with decreased uric acid levels. ${ }^{53}$ Although various interventions have been recommended, no studies have been conducted to directly prove non-pharmacological interventions as related to the prevention of poor CHD prognosis. As a result, more research is required so that nurses can contribute to efforts to prevent poor CHD prognosis through various non-pharmacological interventions based on strong evidence.

This review highlights that uric acid levels are independently associated with CHD prognosis in the elderly population. First, nurses and other health professionals must assess their patients to determine whether they have elevated uric acid. If this is the case, then techniques for dealing with it should be investigated; these may help with the self-management of healthy living choices. Therefore, collaboration with clinical members of the multidisciplinary team is beneficial.

There are several limitations to this study. First, our scoping review was limited to cohort studies and used a small number of databases. Second, this study did not assess the correlation value. Additional research in the form of a systematic review with meta-analysis is required to complete the identification carried out in this study; adjustment is needed for the use of diuretics and renal functionality because the elderly may have renal function problems as they have diabetes and hypertension more often than the younger population. Furthermore, the reviewed studies have a fairly high risk of bias in quality assessment components, particularly implicit reporting of confounding factors identified and adjusted for in the study, reporting of measurement tools in assessing exposure and reporting follow-up time. 


\section{Conclusion}

This study contributes to the growing body of evidence that uric acid levels in the elderly are biomarkers or indicators of poor CHD prognosis. The prognosis of clinical outcomes, severity, and mortality with varying prognostic values is included in the prognosis of associated CHD. Based on the studies that have been carried out, 1) Nurses and other healthcare workers should evaluate uric acid levels as a poor prognosis marker; 2) Based on methodological limitations, this study has not provided a synthesis of evidence in the form of the clinical value of the correlation of uric acid levels with CHD prognosis. Further studies are needed in the form of a systematic review with meta-analysis to synthesize the size of the correlation.

\section{Acknowledgment}

The authors appreciated the Universitas Padjadjaran, Bandung, West Java, Indonesia, for facilitating proofreading service and the database search to conduct this review.

\section{Disclosure}

The authors report no conflicts of interests for this work.

\section{References}

1. Bagheri B, Zargari M, Meshkini F, et al. Uric acid and coronary artery disease, two sides of a single coin: a determinant of antioxidant system or a factor in metabolic syndrome. J Clin Diagn Res. 2016;10(2):OC27-31. doi:10.7860/JCDR/2016/16335.7281

2. Duplancic D, Kukoc-Modun L, Modun D, Radic N. Simple and rapid method for the determination of uric acid-independent antioxidant capacity. Molecules. 2011;16(8):7058-7068. doi:10.3390/molecules16087058

3. Benzie IF, Strain JJ. The ferric reducing ability of plasma (FRAP) as a measure of "antioxidant power": the FRAP assay. Anal Biochem. 1996;239 (1):70-76. doi:10.1006/abio.1996.0292

4. Modun D, Music I, Vukovic J, et al. The increase in human plasma antioxidant capacity after red wine consumption is due to both plasma urate and wine polyphenols. Atherosclerosis. 2008;197(1):250-256. doi:10.1016/j.atherosclerosis.2007.04.002

5. Liang L, Hou X, Bainey KR, et al. The association between hyperuricemia and coronary artery calcification development: a systematic review and meta-analysis. Clin Cardiol. 2019;42(11):1079-1086. doi:10.1002/clc.23266

6. Wijnands JMA, Boonen A, Dagnelie PC, et al. The cross-sectional association between uric acid and atherosclerosis and the role of low-grade inflammation: the codam study. Rheumatol. 2014;53(11):2053-2062. doi:10.1093/rheumatology/keu239

7. Timóteo AT, Lousinha A, Labandeiro J, et al. Serum uric acid: a forgotten prognostic marker in acute coronary syndromes? Eur Hear J Acute Cardiovasc Care. 2013;2(1):44-52. doi:10.1177/2048872612474921

8. Cao HL, Lv B, Chen X, et al. Relation between uric acid and coronary artery calcification: a community-based cross-sectional survey among Beijing natural population. Zhonghua Liu Xing Bing Xue Za Zhi. 2013;1:548.

9. Kiss LZ, Bagyura Z, Csobay-Novák C, et al. Serum Uric Acid Is Independently Associated with Coronary Calcification in an Asymptomatic Population. J Cardiovasc Transl Res. 2019;12(3):204-210. doi:10.1007/s12265-018-9843-8

10. Kim H, Kim SH, Choi AR, et al. Asymptomatic hyperuricemia is independently associated with coronary artery calcification in the absence of overt coronary artery disease. Med. 2017. doi:10.1097/MD.0000000000006565

11. Li M, Hu X, Fan Y, et al. Hyperuricemia and the risk for coronary heart disease morbidity and mortality a systematic review and dose-response meta-analysis. Sci Rep. 2016;6(December 2015):1-11. doi:10.1038/srep19520

12. Zuo T, Liu X, Jiang L, Mao S, Yin X, Guo L. Hyperuricemia and coronary heart disease mortality: a meta-analysis of prospective cohort studies. BMC Cardiovasc Disord. 2016;16(1):1-10. doi:10.1186/s12872-016-0379-z

13. Braga F, Pasqualetti S, Ferraro S, Panteghini M. Hyperuricemia as risk factor for coronary heart disease incidence and mortality in the general population: a systematic review and meta-analysis. Clin Chem Lab Med. 2016;54(1):7-15. doi:10.1515/cclm-2015-0523

14. Bardin T, Richette P. Impact of comorbidities on gout and hyperuricaemia: an update on prevalence and treatment options. BMC. 2017:1-10. doi:10.1186/s12916-017-0890-9

15. Yang Y, Zhou W, Wang YW, Zhou R. Gender-specific association between uric acid level and chronic kidney disease in the elderly health checkup population in China. Ren Fail. 2019;41(1):197-203. doi:10.1080/0886022X.2019.1591994

16. Arksey H, O’Malley L. Scoping studies: towards a methodological framework. Int J Soc Res Methodol. 2005;8(1):19-32. doi:10.1080/ 1364557032000119616

17. Tricco AC, Lillie E, Zarin W, et al. PRISMA extension for scoping reviews (PRISMA-ScR): checklist and explanation. Ann Intern Med. 2018;169 (7):467-473. doi:10.7326/M18-0850

18. Komariah M, Maulana S, Platini H, Pahria T, Scoping A. Review of telenursing's potential as a nursing care delivery model in lung cancer during the COVID-19 Pandemic. J Multidiscip Healthc. 2021;14:3083-3092. doi:10.2147/JMDH.S337732

19. Liberati A, Altman D, Tetzlaff J, et al. The PRISMA statement for reporting systematic reviews and meta-analyses of studies that evaluate health care interventions: explanation and elaboration. Journal of Clinical Epidemiology. 2009;62(10):e1-e34. 
20. Baumann S, Huseynov A, Koepp J, et al. Comparison of Serum Uric Acid, Bilirubin, and C-Reactive Protein as Prognostic Biomarkers of In-Hospital MACE between Women and Men with ST-Segment Elevation Myocardial Infarction. Angiology. 2016;67(3):272-280. doi:10.1177/ 0003319715589246

21. Li Y-H, Lin G-M, Lin C-L, Wang J-H, Chen Y-J, Han C-L. Relation of serum uric acid and body mass index to mortality in high-risk patients with established coronary artery disease: a report from the ET-CHD registry, 1997-2006. J Cardiol. 2013;62(6):354-360. doi:10.1016/j.jjcc.2013.06.002

22. Ndrepepa G, Cassese S, Braun S, et al. A gender-specific analysis of association between hyperuricaemia and cardiovascular events in patients with coronary artery disease. Nutr Metab Cardiovasc Dis. 2013;23(12):1195-1201. doi:10.1016/j.numecd.2013.03.005

23. Ando K, Takahashi H, Watanabe T, et al. Impact of serum uric acid levels on coronary plaque stability evaluated using integrated backscatter intravascular ultrasound in patients with coronary artery disease. J Atheroscler Thromb. 2016;23(8):932-939. doi:10.5551/jat.33951

24. Liu C-W, Liao P-C, Chen K-C, et al. Relationship of serum uric acid and Killip class on mortality after acute ST-segment elevation myocardial infarction and primary percutaneous coronary intervention. Int J Cardiol. 2017;226:26-33. doi:10.1016/j.ijcard.2016.10.025

25. Liu K-L, Lee H-F, Chou S-H, et al. Acute gouty arthritis complicated with acute ST elevation myocardial infarction is independently associated with short- and long-term adverse non-fatal cardiac events. Clin Rheumatol. 2014;33(1):91-98. doi:10.1007/s10067-013-2376-2

26. Lin G-M, Li Y-H, Zheng N-C, et al. Serum uric acid as an independent predictor of mortality in high-risk patients with obstructive coronary artery disease: a prospective observational cohort study from the ET-CHD registry, 1997-2003. J Cardiol. 2013;61(2):122-127. doi:10.1016/j. jjcc.2012.09.004

27. Joo HJ, Jeong HS, Kook H, et al. Impact of hyperuricemia on clinical outcomes after percutaneous coronary intervention for in-stent restenosis. BMC Cardiovasc Disord. 2018;18(1). doi:10.1186/s12872-018-0840-2

28. Lopez-Pineda A, Cordero A, Carratala-Munuera C, et al. Hyperuricemia as a prognostic factor after acute coronary syndrome. Atherosclerosis. 2018;269:229-235. doi:10.1016/j.atherosclerosis.2018.01.017

29. Larsen TR, Gerke O, Diederichsen ACP, et al. The association between uric acid levels and different clinical manifestations of coronary artery disease. Coron Artery Dis. 2018;29(3):194-203. doi:10.1097/MCA.0000000000000593

30. Duran M, Ornek E, Murat SN, et al. High levels of serum uric acid impair development of coronary collaterals in patients with acute coronary syndrome. Angiology. 2012;63(6):472-475. doi:10.1177/0003319711422433

31. Yu J, Han J, Mao J, Guo L, Gao W. Association between serum uric acid level and the severity of coronary artery disease in patients with obstructive coronary artery disease. Chin Med J. 2014;127(6):1039-1045.

32. Teng GG, Ang LW, Saag KG, Yu MC, Yuan JM, Koh WP. Mortality due to coronary heart disease and kidney disease among middle-aged and elderly men and women with gout in the Singapore Chinese Health Study. Ann Rheum Dis. 2012;71(6):924-928. doi:10.1136/ard.2011.200523

33. Berezin AE, Kremzer AA. Serum Uric Acid as a Marker of Coronary Calcification in Patients with Asymptomatic Coronary Artery Disease with Preserved Left Ventricular Pump Function. Cardiol Res Pract. 2013;1-7. doi:10.1155/2013/129369

34. Eisen A, Benderly M, Goldbourt U, Haim M. Is serum uric acid level an independent predictor of heart failure among patients with coronary artery disease? Clin Cardiol. 2013;36(2):110-116. doi:10.1002/clc.22083

35. Ranjith N, Myeni NN, Sartorius B, Mayise C. Association Between Hyperuricemia and Major Adverse Cardiac Events in Patients with Acute Myocardial Infarction. Metab Syndr Relat Disord. 2017;15(1):18-25. doi:10.1089/met.2016.0032

36. Kawabe M, Sato A, Hoshi T, et al. Gender differences in the association between serum uric acid and prognosis in patients with acute coronary syndrome. J Cardiol. 2016;67(2):170-176. doi:10.1016/j.jjcc.2015.05.009

37. Gaubert M, Marlinge M, Alessandrini M, et al. Uric acid levels are associated with endothelial dysfunction and severity of coronary atherosclerosis during a first episode of acute coronary syndrome. Purinergic Signal. 2018;14(2):191-199. doi:10.1007/s11302-018-9604-9

38. Calvo RY, Araneta MRG, Kritz-Silverstein D, Laughlin GA, Barrett-Connor E. Relation of serum uric acid to severity and progression of coronary artery calcium in postmenopausal white and Filipino women (from the Rancho Bernardo study). Am J Cardiol. 2014;113(7):1153-1158. doi:10.1016/j.amjcard.2013.12.022

39. Karabağ Y, Rencuzogullari I, Çağdaş M, et al. Association of serum uric acid levels with SYNTAX score II and long term mortality in the patients with stable angina pectoris who undergo percutaneous coronary interventions due to multivessel and/or unprotected left main disease. Int J Cardiovasc Imaging. 2019;35(1):1-7. doi:10.1007/s10554-018-1446-6

40. Sinan Deveci O, Kabakci G, Okutucu S, et al. The association between serum uric acid level and coronary artery disease. Int J Clin Pract. 2010;64 (7):900-907. doi:10.1111/j.1742-1241.2009.02263.x

41. Sauer B, VanderWeele TJ. Use of Directed Acyclic Graphs. Dev a Protoc Obs Comp Eff Res a User's Guid. 2013;2:177-184.

42. Lindholm D, Lindbäck J, Armstrong PW, et al. Biomarker-Based Risk Model to Predict Cardiovascular Mortality in Patients With Stable Coronary Disease. J Am Coll Cardiol. 2017;70(7):813-826. doi:10.1016/j.jacc.2017.06.030

43. Kaya EB, Yorgun H, Canpolat U, et al. Serum uric acid levels predict the severity and morphology of coronary atherosclerosis detected by multidetector computed tomography. Atherosclerosis. 2010;213(1):178-183. doi:10.1016/j.atherosclerosis.2010.08.077

44. Xia S, Deng SB, Wang Y, et al. Clinical analysis of the risk factors of slow coronary flow. Heart Vessels. 2011;26(5):480-486. doi:10.1007/s00380010-0081-5

45. Maruhashi T, Hisatome I, Kihara Y, Higashi Y. Hyperuricemia and endothelial function: from molecular background to clinical perspectives. Atherosclerosis. 2018;278(October 2018):226-231. doi:10.1016/j.atherosclerosis.2018.10.007

46. Muiesan ML, Agabiti-Rosei C, Paini A, Salvetti M. Uric acid and cardiovascular disease: an update. Eur Cardiol Rev. 2016 ;11(1):54-59. doi:10.15420/ecr.2016:4:2

47. Kang DH, Park SK, Lee IK, Johnson RJ. Uric acid-induced C-reactive protein expression: implication on cell proliferation and nitric oxide production of human vascular cells. J Am Soc Nephrol. 2005;16(12):3553-3562. doi:10.1681/ASN.2005050572

48. Larsen KS, Pottegård A, Lindegaard HM, Hallas J. Effect of Allopurinol on Cardiovascular Outcomes in Hyperuricemic Patients Cohort Study A. Am J Med. 2016;129(3):299-306.e2. doi:10.1016/j.amjmed.2015.11.003

49. Ullah W, Khanal S, Khan R, et al. Efficacy of Allopurinol in Cardiovascular Diseases: a Systematic Review and Meta-Analysis. Cardiol Res. 2020;11(4):226-232. doi:10.14740/cr1066

50. Saito Y, Tanaka A, Node K, Kobayashi Y. Uric acid and cardiovascular disease: a clinical review. J Cardiol. 2021;78(1):51-57. doi:10.1016/j. jjcc.2020.12.013 
51. Kakutani-Hatayama M, Kadoya M, Okazaki H, et al. Nonpharmacological Management of Gout and Hyperuricemia: hints for Better Lifestyle. Am J Lifestyle Med. 2017;11(4):321-329. doi:10.1177/1559827615601973

52. Vedder D, Walrabenstein W, Heslinga M, et al. Dietary interventions for gout and effect on cardiovascular risk factors: a systematic review. Nutrients. 2019;11(12):1-19. doi:10.3390/nu11122955

53. Zhou J, Wang Y, Lian F, et al. Physical exercises and weight loss in obese patients help to improve uric acid. Oncotarget. 2017;8(55):94893-94899. doi:10.18632/oncotarget.22046

\section{Publish your work in this journal}

The Journal of Multidisciplinary Healthcare is an international, peer-reviewed open-access journal that aims to represent and publish research in healthcare areas delivered by practitioners of different disciplines. This includes studies and reviews conducted by multidisciplinary teams as well as research which evaluates the results or conduct of such teams or healthcare processes in general. The journal covers a very wide range of areas and welcomes submissions from practitioners at all levels, from all over the world. The manuscript management system is completely online and includes a very quick and fair peer-review system. Visit http://www.dovepress.com/testimonials.php to read real quotes from published authors.

Submit your manuscript here: https://www.dovepress.com/journal-of-inflammation-research-journal 